\title{
ELIA
}

Estudios de Lingüística Inglesa Aplicada

\section{HERITAGE LANGUAGE SPEAKERS IN UNIVERSITY EDUCATION IN JAPAN: PERSPECTIVES FOR AN INCLUSIVE SOCIETY}

\section{HABLANTES DE HERENCIA EN LA EDUCACIÓN UNIVERSITARIA EN JAPÓN: PERSPECTIVAS PARA UNA SOCIEDAD INCLUSIVA}

\section{Veri Farina Becski}

\author{
UNED, Spain / Kanda University of International Studies, Japan \\ vfarina11@alumno.uned.es
}

\begin{abstract}
The educational system in Japan has traditionally been focused on the "one nation, one language" ideology. This has led to the marginalization of indigenous and immigrant languages. As a consequence, heritage speakers are dealing with the loss of their heritage languages. However, there are isolated movements addressing the maintenance of the heritage languages, though they haven't had a long-lasting effect on the educational system. In an attempt to contribute to reversing this language and identity loss, we based our research on two main points: 1) the belief that creating an informed partnership will help heritage language speakers (HLS) to integrate in the mainstream education space (Cummins, 2014) and 2) confidence in the importance of interconnecting the isolated movements for language maintenance. Would it be possible to achieve it in the Japanese educational context? Can we start scaffolding this new structure of informed partnership from the university level? In order to try to prove this point of view successfully, this article
\end{abstract}


describes the creation at the university level of a class about Heritage languages and speakers in Japan, inspired by the Content and Language Integrated Learning model (CLIL). This class was meant to support and interact with another class called "Spanish for heritage students" that was developed at the same university. The student population is 14 , almost half of them with a heritage language or culture. The course duration was one semester. The contents that were selected to reach the class goals are mentioned, as well as some points of view regarding what should be done to shift the Japanese educational system from a homogeneous stance to a multicultural inclusive posture. And in such a short time we could evidence an evolution in students' critical awareness of the current immigrants' heritage language and cultural situation in Japan. Working with specific vocabulary, reading from authentic sources, discussing contemporary articles among them, they could give shape to their thoughts in Spanish in order to express their opinions and possible solutions to this important matter.

Keywords: Japan, heritage language awareness, heritage speakers, university education, multiculturalism, informed partnership, mainstream society.

\section{Resumen}

El sistema educativo en Japón se ha centrado tradicionalmente en la ideología de "una nación, un idioma". Esto ha llevado a la invisibilización de las lenguas indígenas e inmigrantes. Como consecuencia, los hablantes de herencia están lidiando con la pérdida de sus lenguas heredadas. Sin embargo, aunque existen movimientos aislados que abogan por el mantenimiento de las lenguas heredadas, no tienen un efecto duradero en el sistema educativo. En un intento por apoyar la reversión de esta pérdida de lenguaje e identidad, hemos basado nuestra investigación en 
dos puntos principales: 1) en la creencia de que la creación de una asociación informada facilitará a los hablantes de lenguas heredadas a integrarse en el espacio educativo general (Cummins, 2014) y 2) en la importancia de vincular los movimientos aislados para el mantenimiento del lenguaje. ¿Sería posible lograrlo en el contexto educativo japonés? ¿Podemos comenzar a construir esta nueva estructura de vinculación informada desde el nivel universitario? Para intentar demostrar con éxito este punto de vista, este artículo describe la creación a nivel universitario de una clase llamada Lenguas y hablantes de herencia en Japón, inspirada en el modelo de Aprendizaje Integrado de Contenidos y Lenguas Extranjeras (AICLE). Esta clase está destinada a apoyar e interactuar con otra clase que se desarrolló en la misma universidad llamada "Español para hablantes de herencia". La población estudiantil es de catorce y casi la mitad de ellos tiene alguna lengua o cultura heredada. La duración del curso fue de un semestre. Se mencionan los contenidos que fueron seleccionados para alcanzar los objetivos de la clase, así como algunos puntos de vista de los estudiantes sobre lo que se debe hacer para cambiar el sistema educativo japonés de una postura homogénea a una postura multicultural inclusiva. $\mathrm{Y}$ en tan poco tiempo pudimos evidenciar en los estudiantes una evolución en la conciencia crítica sobre la situación actual de la lengua y cultura de herencia de los inmigrantes en Japón. Trabajando con vocabulario específico, leyendo de fuentes auténticas, discutiendo artículos contemporáneos entre ellos, pudieron dar forma a sus pensamientos en español para expresar sus opiniones y posibles soluciones a este importante asunto.

Palabras clave: Japón, concienciación sobre lenguas de herencia, hablantes de herencia, educación universitaria, multiculturalismo, vinculación informada, sociedad mayoritaria. 


\section{Introduction}

In countries where the policy of "one nation, one language" predominates, other languages are made invisible and people belonging to groups that speak those languages find themselves in a situation of forced assimilation that affects them and their descendants' heritage and emotional integrity. In the case of Japan, education is still focused on the "one nation, one language" ideology, making the country's cultural and linguistic diversity invisible within its own society (Gottlieb, 2012). Although it has been changing in recent years, education still does not reflect, nor even consider enough the existence, or meet the needs of the indigenous Ainu and Okinawan peoples, the immigrant groups and the children of mixed marriages (Japanese-foreigner).

Within the context previously exposed, the following questions were raised: Is it unrealistic to think that heritage languages and cultures can be kept in Japan? How can we create linguistic and social awareness about integration in Japan so as to allow heritage languages to be seen as "resources" and not "problems" (Ruiz, 1984)? Would undergraduate second language learners be interested in acquiring this type of education towards cultural diversity? How to approach the issue of cultural diversity within society without it being seen as a "threatening" idea to the values, culture and morals of Japan? This paper draws on qualitative data and provides details of the students' experience in an attempt to create a model of supporting the heritage language learning - The class of Spanish for Heritage Speakers - at university level by creating a syllabus about Heritage Languages and Speakers in Japan - for an elective subject called Supeingo Kenkyu IV (Spanish studies IV), see 5.2 - where heritage languages and their speaker's situation in Japan are addressed.

The class, Supeingo Kenkyu IV: Heritage Languages and Speakers in Japan, is framed within the context of teaching Spanish 
as a second language. It was originally intended for students in Spanish as a second language. But currently it is aimed at both heritage and non-heritage students of Spanish, and based on the Content and Language Integrated Learning model (CLIL). We believe this method suits very well the purpose of creating critical awareness among university students about the current linguistic and cultural situation of heritage speakers in Japan. With the CLIL model, students are expected to develop their Spanish skills while discussing heritage languages and its learners as such discussions require not only critical thinking, but also the use of specific lexical items and grammatical structures in the target language. CLIL increases students' understanding of academic concepts as well as boosting confidence (Coyle et al., 2013). And this type of class, we hope, will complement the socio-academic context that the classes for heritage speakers need.

\section{Historical context of "one nation-one language" in Japan. An overview}

This section will briefly mention how the policy of 'one nation-one language" has helped to minoritize indigenous and immigrant groups in Japan. Let's begin with the Ainu people. The Hokkaido Former Aborigines Protection Act (1889) had extinguished the rights of the Ainu. According to Tsuneomoto Teraki in an interview for The New York Times (2019), “In Japan's case, for better or for worse, the assimilation policies since the Meiji era (1868-1912) were so successful that almost nothing remains of the Ainu's traditional way of life". It includes their language. As documented by Suzuki \& Oiwa (1997, p. 105-106),

it was only after the new government of Meiji was established in 1868 that the massive migration of (the) Japanese and Colonization of Hokkaido started [...] under the assimilation policy of the government, use of the Ainu 
Heritage language speakers in university education in Japan...

language was forbidden and the culture suppressed by force (sic).

As for the Okinawans, as Gottlieb (2009, p. 24) states, they were caught up in Japan's haste to build a unified modern nation during the Meiji period. [...] In 1879, however, the islands were annexed by the Meiji government and turned into the new prefecture of Okinawa - before it was the Ryukyu Kingdom -. As a result, the indigenous inhabitants of the former kingdom were absorbed [...] by the myth of a mono-ethnic Japan.

There are immigrants who have historically settled in the country, for example, Filipinos, Koreans, Chinese (Gottlieb, 2009; 2012; Suzuki \& Oiwa,1996; Hirabayashi, L. et al., 2002), the children of mixed marriages between Japanese and foreigners, the Nikkei (descendants of Japanese who emigrated to other countries) and the so called dekasegi (Nikkei who for various reasons -political, laboral, economic or family- return to Japan to work, save money and, some of them, go back to their country of origin). As Gottlieb (2012, p. 35) explains, they are

a large group of migrants of Japanese descent (Nikkeijin) from Brazil and to a lesser extent Peru and other South American countries that flocked to Japan in search of work following the 1990 revision of the Immigration Control and Refugee Recognition Act which eased entry requirements for this group in order to meet the labour force requirements of Japanese industry (sic).

There are many actors like social movements, associations, schools, universities - Mundo de Alegría School with Spanish and Brazilian Portuguese lessons in Hamamatsu city, Shizuoka; Asociación Japonés Peruana (AJAPE); the Utsunomiya University 
with the Hands Project, as some examples (Nishikawa, 2019; Matsui \& Farina, 2020) — that support the maintenance of the indigenous and immigrant languages in order to attenuate the impact of the cultural shift that occurs when one migrates (or an indigenous group is assimilated). Unfortunately, these are mainly isolated initiatives that are not part of the mainstream education policy of Japan. However, high priority is given to the study of English (Gottlieb, 2012; Kubota, 2019) and there are not many options for maintaining the heritage languages while going to school. Therefore, students who once dominated their native or heritage language as children end up forgetting it and then have to relearn it as a foreign language when they are young adults, sometimes even after learning English (Nishikawa, 2019; Matsui \& Farina, 2020). This situation begs the question of how to make the Japanese aware of the benefits of promoting and maintaining heritage languages. The answer could be found in confronting the policy of "one country, one language" in mainstream classrooms by highlighting its weaknesses and achievements when compared to the ones of an educational policy that advocates for the wholeness of a country based on its diversity. As stated by Ruiz (1984), the answer is that language should be taken as a resource and not as an obstacle, and we must let regular Japanese students ("regular" meaning non-heritage Japanese) and minority language students - that are studying together in the same only mainstream education system in Japan - reflect on this jointly in order to be aware and find for themselves the viability and the importance of an inclusive education.

However, what can be done to confront the "one language, one country" policy? We could start by identifying isolated initiatives to maintain indigenous, immigrant and/or heritage languages in Japan. They generally arise in regions where these groups are bigger in number. Therefore, it is urgent that these movements bond within the mainstream society. If we do not make this a priority, the 
achievements of these movements will continue to weaken because there is insufficient awareness and true understanding of the multicultural reality of Japan and the importance and benefits of maintaining it. As Macdonald (1995, p. 313) explains,

The diversity of peoples asserting their rights to cultural expression in Japan today are challenging their nationstate to find ways of accommodating difference rather than suppressing it, confident that this will prove a strength rather than a weakness: a society based in mutual respect.

Throughout history, Japanese society has considered itself monocultural and unique, also supported by the Nihonjinron theories (Befu, 2001). Therefore, we should reconsider what Japanese society looks like today. We should consider the new population landscape of Japan after the historical changes that happened before and after World War II: the annexation of Hokkaido and the Ryukyu islands, policies from the Meiji era that included sending the Japanese to live and work abroad, the search for foreign labor to work in Japan, the return of the Nikkei, the marriages of Japanese with foreigners (whose children are called "hafu", half Japanese and half foreigner), "returnee" students (Japanese students who lived and studied for a few years abroad and return to rejoin the Japanese educational system, and who are expected to behave and speak in a perfect "Japanese" way only because of their physical appearance), among other cases. Even though the immigrant population does not represent a large percentage of the Japanese society (about 2.93 percent of the population by 2019 according to Statistics Bureau Japan), they belong there, and they require an appropriate and meaningful education. But while it is true that not many educational systems around the world are prepared to meet the needs of multicultural societies, it doesn't mean that this lack of preparation has to become the rule and that nothing should be done to improve this situation. The perception of the immigrant as a threat to the 
"homogeneity" of society (Gounari, 2014, p. 262) is real in many countries. So, this is where we ask ourselves what we are going to do to tackle this situation, what we have advocated so far: 1) supporting linguistic and cultural awareness in mainstream Japanese society regarding diversity and heritage languages and speakers; 2) creating an inclusive environment to discuss the much-needed educational improvements for this population in Japan. Therefore, we decided to put these principles into practice at Kanda University of International Studies, where students learn languages, many travel abroad as exchange students and share experiences with students of different linguistic and cultural backgrounds that were either born or raised in Japan. All together they are the future, the replacement generation, of Japanese society. History evolves and so must education.

\section{The Content and Language Integrated Learning (CLIL) and heritage languages}

The Content and Language Integrated Learning has been defined by Coyle et. al (2013) as "a dual-focused educational approach in which an additional language is used for the learning and teaching of both content and language [...] there is a focus not only on content, and not only on language [...] each is interwoven" (p.1). Research supports the benefits of this approach in the acquisition of the target language (Perez-Cañado, 2012; Dalton - Puffer, 2008). Though it has been used mainly in mainstream education, this approach could be ideal for heritage or mixed classes with heritage and non-heritage students aiming at the same goal: expanding their knowledge of the Spanish language at the same time they learn academic content or specific topics. The non-heritage students need this kind of immersion-like environment to be able to communicate more fluently in the target language and the heritage speakers need it in order to expand their vocabulary and communication skills in subjects different from the topics they are familiar with. There is a search for appropriate 
pedagogical methods to teach heritage language speakers because of the nature of their diversity. This constitutes a major challenge for heritage language teachers (Polinsky and Kagan, 2007; Lynch, 2003; Charalampidi et al., 2017).

Positive results on including CLIL as an effective pedagogy for the teaching and learning of heritage languages were evidenced by Charalampidi et al. (2017) in a project in a Greek supplementary school in the UK. According to them "the most significant finding was that the approach facilitated the building of linguistic and cognitive bridges between the students' linguistic heritage and their mainstream education”. In the study of this article, we would like to show it can help build a bridge between heritage and non-heritage students towards an inclusive mainstream education and society. Echaikhi (2019) also advocates for the importance of including "in school Arabic Heritage Language classes" in Spanish bilingual education/CLIL context. She also describes the use of Moroccan Arabic and its place as a heritage language in Spain.

Mixing L2 classes with heritage and non-heritage students at university level tends to be very complex situation either for the students or the teacher (Burgo, 2018). It is important to take into account that heritage speakers and L2 learners share a common space. Heritage speakers are somewhere in between of L1 and L2 speakers (Carreira, 2016). And this common place is the one that shows us that they can learn together positively with a proper approach. Thanks to the flexibility of its implementation, CLIL could become a smoother path to successfully teach both type of students together when they already have an intermediate level. CLIL's emphasis on problem solving makes students feel motivated to be able to solve them even in a language other than their mother tongue (Navés and Muñoz, 2000, as cited in Roldán, 2012). According to Marsh in an interview (International House Journal, 2008), "language 
learning becomes 'acquisitional', and not just 'intentional'. 'Acquisition' is an experience that non-heritage students would like to have when learning a second language. Heritage speakers got their heritage language by acquisition basically, though some of them have learned or improved it as a major in a second language learning environment at university level. Therefore, they can continue learning it as if they were in a natural environment. It makes bilingualism in mainstream education realistic and achievable for both heritage and non-heritage students. This way this classroom, where Supeingo Kenkyu: Heritage Languages and speakers in Japan is taught, becomes a 'small scale model' of the supportive Japanese society that Japan needs to create. Two faces of the same coin.

In Japan, the introduction of CLIL has been through English teaching in an important attempt to make language teaching more communicative and significant. But it seems that it is not widely adopted in Japan because of a "lack of suitable material which addresses the needs of the Japanese curriculum at the appropriate level concerning both contents and language (Kane et. al., 2014). The leading institutions that have introduced CLIL in Japanese tertiary education are Sophia University and Saitama Medical University (Ohmori, 2014). There are case studies at university level as reported by Karatsu (2016) or discussion on how fostering CLIL in Japanese Universities would be positive for English language learning (Davies, 2017). There is also an ongoing project called 'An examination into heritage language education through CLIL within Japan and UK' by Kavanagh (2018-2022) that could become an important reference. He is currently doing research on heritage language education with bicultural bilingual children raised in the UK and Japan who are born to a Japanese and non-Japanese parent. In his webinars on this area, he has brought together researchers from both Japan and other countries. 


\section{Method}

The duration of this project was one semester: a 90-minute class once a week for a total of 15 days. Data collection included a survey, activities in Google Classroom with shared documents, short vocabulary tests for self-evaluation, class discussions, in class group activities reports, presentations and essays. On the first day of class, students were given an exploratory survey to find out why they had chosen this class and their learning goals. At the end of the semester, we would be able to evidence their growth at content, linguistic, cognitive, critical and communicative levels through essays and presentations based on the topics students were interested in the most along the course.

Vocabulary related to the topic of heritage languages and its speakers was given before starting a unit. Brainstorms were made and pre-lesson questions were discussed in order to bring personal experiences into the class. This would allow us to understand what the students knew and how could they articulate these words and make them into phrases and opinions in Spanish.

Communication regarding the learning and use of the language was initially developed through content demands adopting a more immersive approach. Students were encouraged to participate orally through the creative use of spontaneous language. In addition, students had to complete written assignments in the Google Classroom (the classes were conducted online because of the pandemic): the class was divided into small groups of 2 to 3 students. They had to discuss among themselves first and then write their answers and opinions regarding two questions found in the shared document that were related to the class that day. There was a space in the shared document for each group to write their answers. For homework, they had to read what the other groups had written and add their respective comments 
and opinions to them. They had to do this homework individually. All the information had to be written in Spanish. This activity let us know their understanding of the topic, if they were getting fluent in the use of the vocabulary and the grammatical needs they had. As Coyle et. al (2013, p. 59) explain, linking the content and cognitive demands with communication (language of, for and through learning),

uses a pragmatic as well as a linguistic approach to
developing language through use. It is not built on a
grammatical model where progression focuses on a
gradation of grammatical concepts, but incorporates
grammatical progression from different perspectives.

Thought-provoking questions were asked in order to generate a natural environment for interventions and opinions. Through this kind of activity, we could see how comfortable the students were speaking in Spanish, explaining contents or using the right vocabulary. Translanguaging was allowed when they worked in groups, in order to give shape to some ideas before putting them into Spanish. This allowed the students and the teacher to identify lexical items or communicative structures that they lack in Spanish, and also pin-point the difficulties they faced when trying to make sense of some of the contents. The evaluation was summative through oral participation in class, the written feedback to the responses of the classmates in the activities of the shared document in Google Classroom (this activity will be explained in section 6), the final essay, and the presentation.

\section{The Project}

\subsection{Start of the project}

At Kanda University of International Studies there is an elective class for Spanish heritage speakers regardless of the degree they study. 
It started in the 2019-20 school year as a pilot project, and the following school year, it became a regular class from which students can earn one credit for each semester they attended. It is a two-semester course called Spanish III B: Spanish for heritage speakers. Students in the aforementioned class take lessons that are tailor-made for their linguistic and cultural needs, and are given the opportunity to reinforce their identity as a whole. For the moment, this is the only class of this type, with credits, at the university level in Japan. For a year it was the only academic endeavor aimed at recognizing the importance of helping Spanish heritage students develop their linguistic skills and fulfil their cultural and identity needs. In order to prevent this important step in education from being an isolated academic endeavor within the university, for the 2020-21 school year a complementary class was created. The class is named Supeingo Kenkyu IV: Heritage Languages and Speakers in Japan (Spanish Studies IV: Heritage Languages and Speakers in Japan).

\subsection{Supeingo Kenkyu IV}

How are the Supeingo Kenkyu IV classes conducted? These are elective research subjects only available for Spanish majors from the Department of Spanish and Portuguese. They are run by different teachers and with different content. Each teacher elaborates his/her syllabus with a topic of their preference or expertise. In our case, it was thought to be important to address the topic of raising critical awareness in mainstream society about heritage languages and speakers in Japan. In a way, this class is inspired, as we have already mentioned, by the CLIL (Content and Language Integrated Learning) approach of teaching a subject through a foreign language while achieving at the same time both linguistic competence and the learning of contents. 


\subsection{Supeingo Kenkyu IV: Heritage Languages and Speakers in Japan}

This is a pilot program with a small number of students (14). Inspired in CLIL, it is a creation of a new syllabus and its content seeks to inform and raise awareness among university students about heritage languages and heritage speakers in Japan at the same time that students expand their linguistic and communicative skills in Spanish as a second or heritage language. Although this class is an exclusive course for undergraduate students who major in Spanish, students from other degree programs who speak intermediate Spanish could audit the class. But, from the 2021-2022 academic year, students from the Spanish Class for Heritage Speakers who don't major in Spanish can join and get credits too.

This course is aimed at second language learners in the third and fourth years of the undergraduate degree in Spanish, which lasts four years and heritage students enrolled in the Spanish for Heritage Speakers' class. They need to have a fairly intermediate level of Spanish, i.e., at least B1-B2 according to the CEFR (Common European Framework of Reference for Languages) because the course is taught in Spanish. Though translanguaging is allowed while they are working in groups in order to organize complex ideas and then write them in Spanish, the students are expected to mostly speak Spanish in class.

It was thought that due to the difficulty of the subject, added to having to study it in Spanish, almost no students would enroll, but surprisingly enough, 14 students ended up enrolling on the class roster. It was also a surprise to see that the students who had signed up included not only those with a heritage language (FilipinoJapanese, Peruvian-Japanese, Chinese-Japanese), or cultural heritage (a Peruvian-Japanese girl who learned Spanish at university), but also students who were interested in the topic (a student whose 
Heritage language speakers in university education in Japan...

undergraduate dissertation is on Japanese as a heritage language in Mexico and a student that was writing his thesis on bilingualism in Puerto Rico), and also a girl of Korean descent and another of Okinawan descent. The other participants were Spanish as a second language students with no heritage language (Table 1). It was a very interesting mixed group because the heritage language students could give their testimonies and provide first-hand answers to the questions that were raised during the class.

Table 1: Supeingo Kenkyu IV. Heritage languages and speakers. Relevant information about the students.

\begin{tabular}{|c|c|c|c|}
\hline & $\begin{array}{l}\text { Heritage } \\
\text { language }\end{array}$ & $\begin{array}{l}\text { Heritage } \\
\text { culture }\end{array}$ & Background \\
\hline Student 1 & $\begin{array}{c}\text { Tagalog } \\
\text { (basic- } \\
\text { intermediate) }\end{array}$ & Filipino & $\begin{array}{l}\text { Philippine mother, } \\
\text { Japanese father. } \\
\text { Born in The } \\
\text { Philippines. } \\
\text { Education in Japan. }\end{array}$ \\
\hline Student 2 & $\begin{array}{c}\text { Spanish } \\
\text { (Intermediate- } \\
\text { advanced) }\end{array}$ & Peruvian & $\begin{array}{l}\text { Immigrated to } \\
\text { Japan at } 5 . \text { Nikkei } \\
\text { and Peruvian mix } \\
\text { race. }\end{array}$ \\
\hline Student 3 & None & $\begin{array}{l}\text { When she was a } \\
\text { child, she was not } \\
\text { aware of the } \\
\text { Peruvian } \\
\text { traditions at } \\
\text { home. She } \\
\text { thought it was } \\
\text { part of the } \\
\text { Japanese } \\
\text { traditions too. }\end{array}$ & $\begin{array}{c}\text { Peruvian } \\
\text { father/Japanese } \\
\text { mother. } \\
\text { Born in Japan. }\end{array}$ \\
\hline
\end{tabular}




\begin{tabular}{|c|c|c|c|}
\hline Student 4 & Chinese & Chinese & $\begin{array}{c}\text { Chinese mother. } \\
\text { Lived in China } \\
\text { until 9 years old. } \\
\text { Continued his } \\
\text { education in Japan }\end{array}$ \\
\hline Student 5 & None & $\begin{array}{c}\text { Maybe some at } \\
\text { home }\end{array}$ & $\begin{array}{c}\text { Born in Japan. } \\
\text { Studied in Japan. } \\
\text { Korean roots. }\end{array}$ \\
\hline $\begin{array}{c}\text { Student 6 } \\
\text { the rest of } \\
\text { students } \\
\text { were native } \\
\text { Japanese } \\
\text { speakers }\end{array}$ & None & Okinawan & $\begin{array}{c}\text { Born in Japan with } \\
\text { Okinawan roots. }\end{array}$ \\
\hline \begin{tabular}{c} 
The \\
\hline
\end{tabular} & None & None & $\begin{array}{c}\text { Born in Japan. Only } \\
\text { Japanese roots. }\end{array}$ \\
\hline
\end{tabular}

\subsection{The program and its duration}

The program of Supeingo Kenkyu $I V$ is designed to be taught in two semesters. But since the subject is elective each semester, not all students who participate in the first semester will necessarily enroll in the second semester. The first semester - the object of this article focuses on heritage languages and speakers in the world and in Japan. In order to describe the general scope of this subject throughout the school year (two semesters), it seems appropriate to roughly comment that the syllabus revolves around Spanish as a heritage language in Japan and, during the second semester, an introduction to its didactics. It includes an end-of-semester assignment (an informative video) that involves raising awareness amongst classmates, teachers and those interested in the subject, on a 
topic they chose from those discussed in the "Spanish as a heritage language in Japan" class. They also have to plan and teach a 10 minutes' lesson aimed at students in the "Class for heritage speakers" at the same university. A group of heritage Spanish students participates in the class and at the end, along with the class teacher, give feedback to their classmates of the "Spanish as a heritage language" class.

\subsection{The general goals of the class}

The fundamental objective of the class is to create critical awareness and enable students to carry out research, read and discuss heritage languages in Spanish and ultimately answer the following questions: 1) what are heritage languages? 2) who are the heritage speakers in Japan? 3) what are their educational needs? and 4) how can we make them visible within society and the framework of Japan's education system? We thought that the best way to make it possible was through classroom interactions and discussions on these topics between second language students and those with a heritage language or culture on the other hand. They are the young people who are going to carry Japanese society forward, the replacement generation. If they understand, value and know what should be done or how a multilingual and multicultural society should be forged, the panorama of Japanese society, of education, tolerance, coexistence and respect will expand and overcome the stagnant system of "one language" and "one education" for a "monolingual" and "monocultural" society. The class does not intend to change the Japanese educational system, but to expand its reach to benefit that part of society that has been quite invisible and neglected. In short, it is about:

- Raising awareness on the issue of heritage languages and heritage speakers in Japan. 
- Generating constructive critical thinking in students through discussions and debates among classmates.

- Creating a comfortable environment where opinions and experiences can be shared between students (considering that heritage language students from several backgrounds could join this lesson too).

The following final objectives were then determined. The students will:

- conduct sociolinguistic group discussions about heritage languages in Spanish, using the specific vocabulary,

- discuss on contemporary real cases,

- investigate and write a final essay raising critical awareness on a chosen topic of heritage languages and heritage speakers studied in class, with an accurate and appropriate vocabulary, and

- present for the class the principal points of the essay.

\subsection{Contents of the program during the first semester}

Below is a list of topics that were deemed to generate productive discussion among classmates. The main topics cover the social reality about heritage languages that does not appear in regulatory texts. These topics would allow second language learners to see the reality in which their peers who have heritage languages have grown up. It also enables heritage speakers to better identify their situation and acquire the necessary knowledge and vocabulary to discuss these issues and propose solutions. The course outline for the first semester is as follows: 
- Introduction to the topic of heritage languages. Historical social context.

- Language policy in Japan.

- Heritage languages in Japan.

- The absence of the heritage speakers and languages in the available teaching materials.

- Specific vocabulary.

- Some linguistic theories related to heritage languages.

- Heritage speakers: immigrants and returnees.

- Identification of the different characteristics of heritage speakers. (Montrul, 2016, Potowski, 2015, Carreira, 2016).

- The Nikkei. Current situation.

- Children who have the "heritage" but not the language.

- The theories of the Nihonjinron.

- Language Shyness.

- Japanese as a heritage language. Migrations to the USA and Latin America.

\section{Activities samples}

\subsection{The exploratory survey at the beginning of the semester}

On the first day of class, as mentioned before, students were given a survey to find out why they had chosen this class and what they hoped to learn in it. Their responses were kept anonymous. It was thought that this way they could answer more freely. In Japan, for some students, it is not easy to say that they are of mixed origin in front of their peers. Sometimes that category is accompanied by social stigma. 
The Japanese are very private in general. Information about their interest in this subject was obtained through the students' responses. Most were interested in the topic, but from different perspectives. Here is a list of some of the answers:

- My mother is from the Philippines and my father is Japanese.

- My father is Peruvian, but he never spoke to me in Spanish.

- I have a heritage culture and I want to know more.

- My parents are from Okinawa, so I belong to this group.

- I want to help foreigners in the future.

- I'm interested in the topic (9 students).

Through the survey, it was possible to know the origin and interest of the students in this class. That allowed us to keep anonymous the origin of the students who did not want to make it public, but also provided an opportunity to cover their concerns throughout the course, with the hope that at some point they would feel confident enough to talk about their individual experiences in class. We were also able to find out if our program does not cover a topic of interest or the origin or specific situation of a student.

\subsection{Topic for discussion during the class}

The topic was unfamiliar to a group of students, while others had seen classmates at school going through that experience and for others it was their personal experience at school. In 2019-20 we found the following newspaper headlines related to our topic about language policy in Japan and immigration:

- Japan's first literacy study in 71 years will include foreigners. (International Press, 2019). 
- Japanese authorities do not know if 16,000 foreigners attend school (International Press, 2019).

- Foreign students in Japan have reportedly been mistakenly diagnosed as disabled (as having a low IQ) (International Press, 2019).

- Japan will double the budget for foreign children to study (International Press 2020).

Students had to read a newspaper article that reported that foreign students from a primary school had been mistakenly placed in the class for "special children" for not having demonstrated sufficient IQ after a placement test that had been given in Japanese and with specific questions regarding the history of Japan. This article triggered a debate between heritage and non-heritage students. They were saying that students should be supported in learning the Japanese language. The conclusion of the debate was that this support in regard to the Japanese language must be accompanied by the reinforcement of the heritage language and culture for immigrant students. They defended that this support should be provided while the students are still learning Japanese, otherwise they would be able to acquire sufficient knowledge neither in Japanese nor in their heritage language. Since the classes are taught in Japanese, they would need to master the Japanese language academically before really understanding the contents of such lessons. And without the opportunity to study the heritage language, they lack proficiency in both languages causing them to lose academic years. Students also said that for this to be understood and to happen, it is necessary to show the reality of the needs of these different groups (immigrant students, children of mixed marriages, indigenous groups, etc.) to the rest of the Japanese society. Ordinary people are not aware of what is happening, hence they cannot help. For this, it is necessary to inform the educational community and provide academic training on how to 
receive these children in schools. It is also important for educators to learn how to support these children in the process of learning Japanese while at the same time not being ashamed of their heritage and not losing an important part of their identity. It was impressive to see how keen the students were to understand what was happening, listen to the experiences of the heritage peers and think together about solutions. Finally, they came to an understanding that there is a lack of information and awareness and not a lack of interest or respect from the society in general.

\subsection{Scaffolding in order to teach linguistic content}

\subsubsection{Scaffolding Vocabulary}

Taking into account that this topic about heritage languages and heritage speakers was taught within a second language learning context, inspired by the CLIL model, it was necessary to move slowly, forming a solid base, and scaffolding the transition towards discussions and reflections on this topic. The course began with attempts to understand what a heritage language is. The students were asked about their knowledge on this topic or personal experiences. Instead of providing a definition, students were taken through different contexts that define it to conclude that there is no standard definition or that any definition would have to be very broad in order to cover all cases of heritage languages (Montrul, 2016). Then, different cases of language contact were explained, including the Japanese context. At this point there were group discussions that afterwards were shared with the entire class.

When necessary, the students were sent a short list of specific vocabulary items that the teacher considered of special importance to be used in the following lesson. Students had to find their meanings and submit them through Google Classroom the day before the class. This way they started doing some research and preparation before class. The objective was to make them at least familiar with the 
vocabulary. Also, the teacher could see what they had found, correct if there was something wrong and send it to them before the class started. In class, doubts were dispelled and vocabulary was explained as it appeared in the context of the class. As they used the vocabulary and became familiar with it, they had to incorporate it into their discussions and essays. Below is a sample of vocabulary studied in this class:

Herencia (heritage), lengua heredada (heritage language), hablantes de herencia (heritage speakers), sociopolítico (sociopolitical), lengua mayoritaria (mainstream language), lengua minoritaria (minority language), lengua oficial (official language), lengua cooficial (co-official language), etnolingüístico (ethnolinguistic), marginalizado (marginalized), demográfico (demographic), inmigración (immigration), colonización (colonization), Lenguas en contacto (language contact), bilingüismo (bilingualism), competencias lingüísticas (linguistic competences), primera lengua (first language), segunda lengua (second language), Adquisición bilingüe de la primera lengua (Bilingual First Language Acquisition, BFLA) (De Houwer, 2009).

Next, the teacher would leave a thought-provoking question for them to discuss in groups (and later with the whole class) and ask them to use the vocabulary she had given them. That way she could confirm whether or not they had understood, or if they used the words correctly or not. As homework, they had to read the PowerPoint presentation used in class and make sure that they understood what was written there. If not, they had to prepare the questions for the teacher to answer in the next class. They also had to look for examples of heritage languages to present in the next class. There was a lot of effort by the students in terms of being able to describe the heritage languages, who is and who is not a heritage speaker according to their personal context, and give examples of friends or acquaintances. 
As a task, they had to define in their own words "heritage language" based on what they had understood in class, and give examples. In addition, they had to use the correct terminology that was on the vocabulary list whenever applicable. This gave the teacher the opportunity to verify again the correct understanding and use of specific vocabulary and to communicate with the student in case it had not been used well. At this point, they were asked to find a definition of heritage language and heritage speakers in Japanese and translate it into Spanish to affirm all knowledge with the help of the Japanese referent (which they would surely have used before for support). They had to submit to the teacher the original in Japanese along with the translation. This activity also allows students to become familiar with this linguistic terminology in Japanese.

\subsubsection{Scaffolding discussions, writing and grammar}

Example of class discussion work were:

- For heritage speakers is the heritage language (HL) L1 or is it L2?

- How do you think it is related to identity? Can you give examples?

The questions above were part of an activity that was conducted in discussion groups and then students had to write their responses in a collaborative document (in Google Classroom). Everyone had to read what was written by the other groups and comment on what they found most interesting or complete with information or details that were absent. Each group had a heritage speaker in it which made the discussion very interesting, because they were explaining that they felt HL was in the middle between L1 and L2. In this space, the teacher had the opportunity to realize the grammar that each student lacked in order to express some of their opinions. At that time, she took the opportunity to explain 
individually, in writing (in the shared document) the grammar that the students needed to properly express their opinion in Spanish. As the document was shared and as all the students had to read it, they had the opportunity to learn from the explanations written by the teacher to their classmates. And if there were grammatical needs, both oral and written, common to most of the students, a part of the lesson was taken to explain it.

\subsubsection{Scaffolding reading in Spanish}

This was a group reading activity with key questions to confirm understanding of the main points of the text: “The heritage speaker" (Potowski, 2015).

There were questions for discussion after the lecture:

- Do you think that it is essential for a Spanish teacher to know the characteristics of his students to be able to teach efficiently in a class of Spanish as a heritage language for natives? (Potowski, 2015, p. 73; adapted to the Japanese context).

Imagine that you have to work with a group of JapaneseHispanics. Do you think it would be useful for you, as teachers, to know the origin of your students? How would you search for information about the culture of your students? Think of an activity that goes beyond the question "You, where are you from?" and that, at the same time, it can serve to know the level of competence or command of Spanish of their heritage students.

The students discussed some of the problems that heritage speakers go through, their consequences and possible remedies. There were discussions about marginalization, assimilation, acculturation, harassment or rejection, and also about language shyness when speaking. For this topic, Krashen's (1998) article on Language Shyness was used. 
With these readings the non-heritage students could come closer to understand the reality of the needs in school education of heritage speakers in Japan. The heritage students could better understand what has been happening to them in school education and how to address these problems with the proper words.

\subsection{End of semester project}

- The topic: choose the topic that interested you the most during the course.

- Write an essay

- Make a PowerPoint presentation about your essay

- The discussion session: answer the questions you are asked about your presentation.

Following some comments from students in their final essays that show the degree of awareness they reached during the semester. The original version that the students wrote will be kept in order to appreciate their written fluency and the use of the vocabulary.

First, we will show some of the titles of the essays ${ }^{1}$ :

- Student 1. "El tagalog como lengua de herencia en Japón: las dificultades de los alumnos filipinos". ("Tagalog as a heritage language in Japan: the difficulties faced by Filipino students”.)

- Student 2. "La importancia de la ayuda activa para lenguas minoritarias en Japón: el caso de los ainu" ("The importance of active help for minority languages in Japan: the case of the Ainu".)

\footnotetext{
${ }^{1}$ The numbering of the students in this section is not related to the one assigned in Table 1. 
Heritage language speakers in university education in Japan...

- Student 3. "La enseñanza del japonés como lengua de herencia en México". ("The teaching of Japanese as a heritage language in Mexico".)

- Student 4. "Relación entre el nihonjinron y la educación en Japón". ("The link between nihonjinron and education in Japan".)

- Student 5. "La enseñanza de las lenguas de herencia para los adolescentes a quienes nunca se la hablaron". ("Teaching a heritage language to adolescents who have never been spoken to in theirs".)

- Student 6. "El guaraní como lengua de herencia de los nikkei paraguayos en Japón”. ("Guaraní as the heritage language of the Paraguayan Nikkei in Japan".)

- Student 7. "La educación sobre la diversidad cultural en la sociedad japonesa". ("Education on cultural diversity in Japanese society”.)

Second. Some comments from the students

Student 1. He addresses his own personal experience about identity and nationality.

Inmigrar es difícil para los adultos, pero más difícil para los niños:

Es dificil ir a la escuela donde nadie te entiende.

Es duro olvidarse del tagalog.

Es injusto tener que elegir nacionalidad a los 22 años en Japón. Esta nacionalidad la han traído con ellos y es parte de su identidad: ¿Elegir entre mamá y papá? [Immigrating is difficult for adults, but more difficult for children:

It's hard to go to school where no one understands you. It's hard to forget Tagalog. 
It is unfair to have to choose nationality at the age of 22 in Japan. They have brought this Nationality with them and it is part of their identity: choosing between mom and dad?]

Student 2. He chose to talk about the myth of the Japanese homogenous society, assimilation and linguistic shyness.

¿Es mi país homogéneo lingüísticamente? El ainu itak (la lengua ainu) ha sufrido discriminación y como consecuencia muchos hablantes han sentido vergüenza. [Is my country linguistically homogeneous? Ainu Itak (The Ainu language) has suffered discrimination and as a consequence many speakers have felt ashamed.]

Student 3. She suggests that we must consider the teaching of Japanese as a heritage language abroad. This is how you can see Japan's attitude towards heritage speakers of Japanese.

Cuando pensamos cómo podemos cambiar ese problema dentro de Japón, hay que considerar la situación afuera $o$ sea la enseñanza del japonés como lengua de herencia. Así se puede observar la postura de Japón para la propia lengua de herencia.

[When we think about how we can change that problem within Japan, we have to consider the situation outside that is the teaching of Japanese as a heritage language. This is how you can see the position of Japan for its own heritage language.]

Student 4. This student got interested in helping heritage speakers not to lose their heritage language. We could consider this a success, a step forward.

Algunos alumnos comienzan a aprender tardíamente su lengua de herencia. Entonces hay que comenzar a explicarles. Me gustaría apoyarlos para que aprendan la lengua de sus padres. 
Heritage language speakers in university education in Japan...

[Some students begin to learn their heritage language late.

Then you have to start explaining to them. I would like to support them to learn the language of their parents.]

Student 7. She is concerned about the lack of preparation of Japanese society to cope with its own diversity. But advises that Japanese education does not need to be modified, but adapted to that reality.

¿Creen ustedes que la educación en Japón está preparada para la diversidad cultural? No es necesario modificar la educación japonesa, sino adecuarla a la diversidad cultural porque a medida que pasa el tiempo el mundo está interconectándose y la sociedad japonesa está transformándose a la diversidad.

[Do you think that education in Japan is prepared for cultural diversity? It is not necessary to modify Japanese education, but to adapt it to cultural diversity because as time passes the world is interconnecting and Japanese society is transforming to diversity.]

All these comments, if compared with the answers of the Survey at the beginning of the semester, show how the students appropriate the language and analyzed the problems, giving punctual solutions to them from a critical point of view. We can perceive a maturity in the understanding and communicating regarding the topic which could mean a positive change in the short term for the future education of heritage speakers.

\subsection{Some challenges and limitations}

One of the challenges posed by this subject was how to teach "linguistics" in Spanish to students who are learning Spanish as a foreign/heritage language. It was necessary to confirm if they had understood the basic specific vocabulary in order to be linguistically prepared to understand the contents of the class and to be able to 
carry out analyses and discussions. We needed to translate into Spanish many of the important linguistic texts used for the class as they are manly written in English.

There are still limitations for this project in terms of the small number of students who have access to this class, which may be caused by the fact that it is aimed at students with intermediate proficiency in Spanish. It should be possible to offer this course at different levels of language proficiency since the purpose of the class would not change. Another limitation that worries us is that it is not a fixed subject. If the subject teacher is replaced, the syllabus will most likely be removed because each teacher chooses what topics to teach in Supeingo Kenkyu $I V$.

\section{Proposal}

For the time being, universities should lead efforts aimed at raising awareness about heritage languages and their speakers. We consider that, in university language departments where the foreign language studied is also a heritage language in Japan, a content subject about heritage languages and their speakers should be introduced too. We believe CLIL is the most suitable approach to teach the content subject through use of the target language. This CLIL class would allow non-heritage -with an intermediate level of the target language- and heritage -with a high level of oral and written proficiency in their heritage language- speakers, all together in one class, to use the language appropriately while they learn it effectively. Students would relate content to thinking and learning, and this would allow them to find out more about what is required of them to communicate effectively. From there it will be possible to know their specific grammatical needs, and to prepare the linguistic support they need. Furthermore, the learning environment that emerges through CLIL allows for a natural way of interacting that creates 
critical intercultural awareness. Finally, we recommend that this class be accessible to students who major in other fields at the university.

\section{Conclusions}

If we compare and analyze the survey carried out at the beginning of the semester - how insecure the student's language was and how unclear they were on the subject of heritage languages - with the content of the essays at the end of the semester, there is evidence of growth in the understanding of this social reality, and how to express it using Spanish. The heritage and non-heritage students have reasoned and sought solutions together which has helped to consolidate their position in the face of social injustice. The use of the learned vocabulary has been correct in its context and critical thinking is seen through the use of Spanish. This type of activity can be considered positive within the field of teaching of and about heritage languages.

This greater understanding and teamwork in a coordinated manner in the classroom through CLIL could bring great linguistic, cultural and human benefits for both heritage speakers and those who do not have a heritage language because they complement each other. Without the two sides of the coin, there is no coin. Heritage Spanish speakers and students of Spanish as a second language, all together, make up the Spanish language landscape in Japan.

It is expected that this class would become an independent and fixed subject in the Spanish department - ceasing to be part of Supeingo Kenkyu $I V$ - and that there would be similar classes in other language departments at the university. But this has yet to happen since for now Spanish is the only department with an accredited Spanish class for its native and heritage 
speakers. This project must reach all university students. Heritage languages must be discussed in classes on linguistic and educational policies, sociology, anthropology, etc. From there, radical change can begin through the process of training all those who are going to make the decisions for the education of tomorrow in Japan. Meanwhile we can go on supporting teachers who do not know how to face this type of educational challenge and also informing school officials, etc.

Students who have grown up and studied in Japan understand the educational system. They know the weak and strong points, where it fails and where it needs to be strengthened. We are sure that if topics such as heritage languages, heritage speakers, education, educational policies and social planning in Japan were made into a university course in Japanese universities, it could become a meeting point between heritage speakers and non-heritage speakers. It would also reach many more people in Japanese society, eliminating educational and social barriers and making visible this important part of Japanese society that is not "officially" represented. Because as Cummins (2014) suggests, creating a context of informed partnership will help integrate better heritage language speakers in the long term into the school system and the mainstream educational space.

The students who signed up for this class who are interested in helping foreigners and people who have a heritage language need to be educated and trained to be able to fulfil their mission with the necessary tools. It was interesting that only with a semester of class they realized the magnitude of what they did not know about their own society members. It is noted that the lack of action at governmental level is, among other reasons, due to a lack of knowledge of this problem, thus making these groups somehow invisible. The students were very critical of this failure and 
Heritage language speakers in university education in Japan...

immediately looked for solutions. The class shared empathy with the struggle of heritage speakers, a sentiment illustrated in the phrase "It's everyone's battle".

\section{References}

Befu, H. (2001). Hegemony of Homogeneity. Melbourne, Australia: Trans Pacific Press.

Carreira, M. (2016). Teaching Spanish Heritage Language Learners. The 2016 Heritage Spanish Workshop.

Charalampidi, M., Hammond,M., Hadjipavlou, N. \& Lophitis, N. (2017). A Content and Language integrated Learning (CLIL) Project: Opportunities and Challenges in the Context of Heritage Language Education. The European Conference on Language. https://www.researchgate.net/publication/317837264_A_Content_a nd_Language_Integrated_Learning_CLIL_Project_Opportunities_a nd_Challenges_in_the_Context_of_Heritage_Language_Education

Coyle, D., Hood, P., \& Marsh, D. (2013). CLIL. Content and Language Integrated Learning. United Kingdom: Cambridge University Press.

Cummins, J. (2014). Mainstreaming plurilingualism: Restructuring Heritage Language Provision in Schools. In P. \&. Tifonas, Rethinking Heritage Language Education (pp. 1-19). United Kingdom: Cambridge University Press in Content and Language Integrated Learning.

Dalton-Puffer, C. (2008). Outcomes and processes in content and language integrated learning (CLIL): current research from Europe. In W.Delanoy \& L. Volkmann, (Eds.) Future Perspective for English Language Teaching (pp. 139-157). Heidelberg: Carl Winter.

https://doi.org/10.1075/11lt.20

Davis, M.J., (2017, January). The Case for Increasing CLIL in Japanese Universities. Ritsumeikan Studies in Language and Culture 28(3) $195-205$.

De Houwer, A. (2009). Bilingual First Language Acquisition . Bristol: Multilingual Matters.

https://doi.org/10.21832/9781847691507 
Echaikhi, F. (2019). Problematising the Absence of Heritage Languages in CLIL schools: The case of Moroccan Arabic in Spain. Master Thesis. Universidad Complutense de Madrid.

https://eprints.ucm.es/id/eprint/61114/12/TFM_Echaikhi,\%20Fátim a_2019.pdf

Gottlieb, N. (2009). Language and Society in Japan. United Kingdom: Cambridge University Press.

Gottlieb, N. (2012). Language Policy in Japan. The challenge of change. United Kingdom: Cambridge University Press. https://doi.org/10.1017/CBO9781139017510

Gounari, P. (2014). Rethinking Heritage Languages in a Critical Pedagogy Framework. In P. \&. Tifonas, Rethinking Heritage Language Education (pp. 254-268). United Kingdom: Cambridge University Press.

Hirabayashi, L., Kimura-Yano, A., \& Hirabayashi, J. (2002). New Worlds, New Lives, Globalization and People of Japanese Descent in the Americas and From Latin America in Japan. California: Stanford University Press.

International Press, (2019, June, 12). Primer estudio de alfabetización en Japón en 71 años incluirá a extranjeros.

https://internationalpress.jp/2019/06/12/primer-estudio-dealfabetizacion-en-japon-en-71-anos-incluira-a-extranjeros/

International Press (2019, January, 7). Autoridades japonesas no saben si más de 16.000 niños extranjeros asisten a la escuela.

https://internationalpress.jp/2019/01/07/autoridades-japonesas-nosaben-si-mas-de-16-000-ninos-extranjeros-asisten-a-la-escuela/

International Press (2019, September, 4) Estudiantes extranjeros en Japón habrían sido diagnosticados por error como discapacitados. https://internationalpress.jp/2019/09/04/estudiantes-extranjeros-enjapon-habrian-sido-diagnosticados-por-error-como-discapacitados/

International Press, (2020, September, 4). Japón duplicará presupuesto para que niños.

https://internationalpress.jp/2020/09/04/japon-duplicarapresupuesto-para-que-ninos-extranjeros-puedan-estudiar/

Kane, E., Tanaka, Y.\& Kobayashi, A.(2014). Scaffolding content-driven Teaching for Language Learners: implications for CLIL Courses at 
Heritage language speakers in university education in Japan...

the University of Shimane, Shimane University Sogo Seisa 27, pp. 126-149.

https://www.semanticscholar.org/paper/Scaffolding-Contentdriven-Teaching-for-Language-\%3A-KaneTanaka/3ba7dbbb7c0e2cbf7e2f183f21f06101d8d05173

Karatsu, R. (2016). Fostering Critical Intercultural Competence in CLIL. Classes Through Films: A case study at a Japanese University. https://www.jstage.jst.go.jp/article/atem/21/0/21_129/_pdf

Kavanagh, B. (2018, July). The potential of CLIL as an effective pedagogy and learning of heritage languages. A case of study of a supplementary Japanese school in the UK.

Krashen, S. (1998). Language Shyness and Heritage Language Development. In S. Krashen, L. Tse, \& Mc Quillan, Heritage Language Development. California: Language Education Associates.

Kubota, R. (2019). Nihon ni okeru gaikoku ni rutsu wo motsu kodomo no tameno keyshougo kyouiku to gengo seisaku. [Language policies and Heritage Language education for Foreign Children with Roots in Japan]. In K. Kondo, M. Sakamoto, \& T. Nishikawa, Oya to ko wo tsunagu keishogo kyoiku [Heritage Language Education Connecting Generations] (pp. 268-282). Japan: Kurosio.

Lynch, A. (2003). The relationship between second and heritage language acquisition: notes on research and theory building. Heritage Language Journal, 1, pp.26-43.

https://doi.org/10.46538/hlj.1.1.2

Marsh, D. (2009, December 30). CLIL: An interview with Professor David Marsh. International House Journal.

Mcdonald, G. (1995). The Politics of Diversity in the Nation-State. In J. Maher, \& G. Mcdonald, Diversity in Japanese Culture and Language (pp. 291-313). London: Kegan Paul International.

Matsui, K. \& Farina, V. (2020). La enseñanza del español como lengua de herencia a nivel universitario en Japón: un proyecto y un desafío. Kanda University of International Studies Language Research Center (31) 1-33. 
Montrul, S. (2016). The Acquisition of Heritage Languages. United Kingdom: Cambridge University Press.

https://doi.org/10.1017/CBO9781139030502

Navés, T., \& Muñoz, C. (2000). Usar las Lenguas Extranjeras para Aprender y Aprender a Usarlas Lenguas Extranjeras. Una introducción a AICLE para madres, padres, y jóvenes. In D. Marsh \& G. Langé (Eds.), Using Languages to Learn and Learning to Use Languages (pp. 1-15).

Nishikawa, T. (2019). Nihon no koritsugakko ni okeru nihongo wo bogo to shinai kodomo e no tengo kyoiku. [Education in Public Schools in Japan for Children who do not have Japanese as their mother tongue]. In K. Kondo, M. Sakamoto, \& T. Nishikawa, Oya to ko wo tsunagu keishogo kyoiku [Heritage Languages education connecting generations] (pp. 209-223). Japan: Kurosio.

Ohmori, A. (2014). Exploring the potential of CLIL in English Language teaching in Japanese universities: An Innovation for the development of effective teaching and global awareness. The Journal of Rikkyo University Language Center, 32, pp.39-51.

Onishi, N. (2008, July 3). Recognition for a people who faded as Japan grew. The New York Times.

Perez-Cañado, M.L (2012). CLIL research in Europe: past, present, and future. International Journal of Bilingual Education and Bilingualism, 15(3), pp. 315-341).

https://doi.org/10.1080/13670050.2011.630064

Polinski, M., \& Kagan, O. (2007). Heritage Languages: In the 'Wild' and in the Classroom. Language and Linguistics Compass, 1(5), pp.368395.

https://doi.org/10.1111/j.1749-818X.2007.00022.x

Potowski, K. (2015). Fundamentos de la enseñanza del español a hispanohablantes en los EE.UU. España: Arco Libros, S.L.

Ruiz, R. (2017). Orientations in Language Planning. In N. Hornberger, Honoring Richard Ruiz and his Work on Language Planning and Bilingual Education. Bristol: Multilingual Matters. https://doi.org/10.21832/9781783096701-004 
Heritage language speakers in university education in Japan...

Statistics Bureau Japan.

https://www.stat.go.jp

Suzuki, D., \& Oiwa, K. (1996). The Japan we Never Knew. A journey of discovery. Canada: Allen \& Unwind.

First version received: September, 2021

Final version accepted: November, 2021 